\title{
Patterns of Reporting
}

Fields, Countries, Ideology, and Gender

Varying degrees of influence come into full view when we examine the relationship between, on the one hand, the human rights, humanitarian aid, and diplomacy fields, with their conflicting representations of the Darfur conflict, and patterns of media reporting, on the other. The link between the judicial or human rights field and media suggests a seeming paradox. Asked about the ICC as a potential source of information, one German Africa-correspondent answered: "Not at all, and I find this really quite regrettable." A French journalist, speaking about his relationship to the ICC told me that "[t]heir time is not our time." Yet, as we shall see, the impact of the judicial field, specifically ICC interventions, on media representations of mass violence is quite remarkable. That impact certainly appears more pronounced than the traces the humanitarian and diplomatic fields leave in journalistic reporting.

In this chapter I describe and seek to explain actual patterns of media representation of Darfur. I speak to ways in which Africa correspondents, acting in the journalism field, with the habitus described in the previous chapter, improvise as they apply the rules of the journalistic game in practice. I explore how they adapt to external pressures and to the constraints they face. I primarily draw on the Darfur media data set, based on the content analysis of 3,387 articles described in the introduction. These data tell us when newspapers began reporting about Darfur and how the number of reports, the depiction of suffering, and the framing of violence changed over time. They also gauge the effect of 
interventions by actors from surrounding social fields. I show that outside pressures to which the journalistic field is exposed are substantial. They include media markets; economic dependency on advertisers and subscribers (who have become scarcer and thus more valuable in the early twenty-first century); agendas of political actors who impede journalism (in the targeted country or area) and who validate journalistic attention to issues (in the home country); and information dependency on societal sectors that include the judicial, humanitarian, and diplomatic fields. Finally, patterns reveal similarities and differences across countries. Interviews with Africa correspondents help make sense of these patterns. The chapter's conclusions address central Bourdieuian arguments regarding the position of journalism in fields of power, specifically journalism's relationship to neighboring fields, forces that must be considered if we want to make sense of variations in reporting about mass violence in Darfur or elsewhere (Bourdieu I998; Benson I998, 2006). The conclusions further add new information to past scholarship about boundaries between political and journalistic fields and debates about the mediatization of politics (Mazzoleni and Schulz I999; Revers 20I4; Strömbeck and Esser 20I4). They enrich insights from research and journalistic self-reflections on the reporting about mass violence in Africa (Allen and Seaton I999; Crilly 20I0; McNulty I999; Mody 20I0; Ray 2009; Thompson 20II). And they contribute new, internationally comparative findings to those gained through a small body of previous comparative scholarship (e.g., Benson I998, 2013).

INTENSITY OF REPORTING: THE JOURNALISTIC VIS-À-VIS THE POLITICAL FIELD AND MEDIA MARKETS

How much attention did media pay to the mass violence in Darfur, and how did the intensity of reporting change over time? Figure 2 I depicts how the number of media reports from each country changed from year to year during the conflict. The numbers in this figure reflect the entire population of articles about Darfur that my research team identified in the fourteen newspapers and from which the sample of 3,387 articles was drawn for detailed analysis. It is instructive to follow these lines year by year.

Note first that shifts in the intensity of reporting developed in almost perfect unison. Within the same year a peak in the number of articles in one country is mirrored in those of the other countries. The massive volume of reporting in 2004 and 2007 stands out for all countries. 


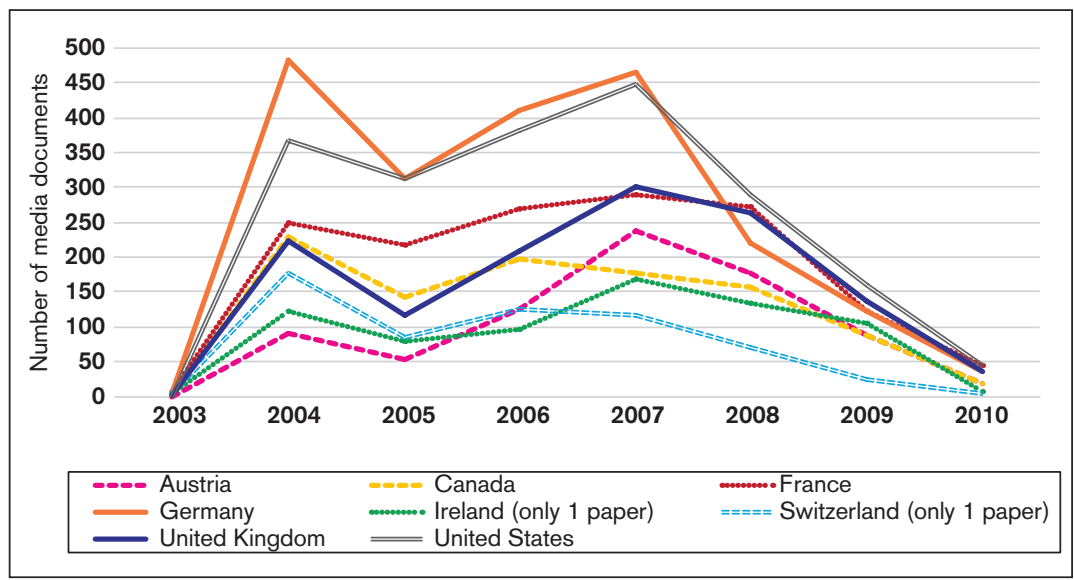

FIGURE 2 I. Number of articles on Darfur appearing in fourteen Northern newspapers, by country over time.

Second, though, the intensity of reporting differs considerably across countries. The lines for Germany and the United States by far exceed those of the other countries. For the United States this is consistent with the massive civil society movement around the Darfur issue, paralleled by the particularly outspoken engagement of government actors. For Germany the higher level of reporting corresponds with that country's articulation of special historical responsibility. It is also consistent with the generally greater engagement with genocide in German political discourse, as diagnosed by K. Smith (20I0) in her comparative analysis of large European countries. In our analysis, frequency of reporting in US and German newspapers is followed-in most years and with considerable distance-by papers in the UK and France, the former colonial powers in Sudan and neighboring Chad, respectively. Note that Ireland and Switzerland are represented by only one newspaper. If we account for the fact that only one paper was analyzed, the Irish intensity of reporting also stands out, in line with the substantial humanitarian engagement in Darfur of Irish aid NGOs and the Irish government (see chapter 5$).{ }^{\mathrm{T}}$

Beyond the overall volume of reporting, the cycles of media reports about Darfur across specific time periods pose urgent puzzles. I here spell them out and seek explanations. Virtually no reports appeared in 2003 Yet the first wave of massive killings and displacements unfolded between April and September of that year before it subsided following a temporary cease-fire. This journalistic silence, paralleling disregard or 
denial in other fields, is of course not the first case in which media have responded late to mass violence on the African continent. ${ }^{2}$

The second massive wave of killings took place between December 2003 and April 2004, when a second cease-fire took effect. At this point media did begin to take notice, and later in 2004 , the intensity of reporting actually reached high levels. ${ }^{3}$ This new wave of violence differed little from the first and thus might have been accompanied by similar media apathy. But this time the violence went along with highly visible civil society and political responses. As early as December 2003, UN secretary-general Kofi Annan's special envoy Tom Eric Vraalsen reported that the government of Sudan was denying humanitarian access to Darfur. In January 2004, the USHMM issued a "genocide alert" for Darfur. In February, the Washington Post published an op-ed piece by scholar-activist Eric Reeves on the violence in Darfur, and one month later the New York Times followed with an op-ed by Nicholas Kristof. ${ }^{4}$ These pioneers, interestingly, did not include correspondents who were actually working in the field in Africa. Only one month after the second, much noted op-ed, Kofi Annan delivered his famous speech before the UN General Assembly on the tenth anniversary of the Rwandan genocide. By late summer 2004, in the United States the George W. Bush administration began using the term genocide, and in September 2004 the UN Security Council charged the International Commission of Inquiry on Darfur to report on the violence. I spell this and other events of 2004 out in greater detail in chapter I.

Some journalist interviewees addressed factors that motivated their first reporting about Darfur in early 2004. Their statements reveal that the political field generally and the United Nations specifically, as well as human rights NGOs, played a central role in sparking initial journalistic engagement. A distinguished Africa correspondent recalled: "When first messages about a new war in Sudan appeared in 2003, I initially did not take that so seriously. But when the commemorative events unfolded on the tenth anniversary of the Rwandan genocide [April 2004] and Kofi Annan and others said, 'We will no longer tolerate this,' then I also decided to take this conflict seriously and I traveled there" (author's translation).

Another journalist told about his work on the North-South conflict in Sudan and the relief he and his colleagues had felt when the Comprehensive Peace Agreement (CPA) was signed in 2005 . Having worked on the North-South conflict in the preceding years, his attention was thus attuned to Sudanese issues. Yet it took an unusual series of events 
for him to begin his field trips and reporting from Darfur and Chad. Tracing the takeoff of reporting in this journalist's paper is instructive: "We then regularly received messages from human rights organizations informing us of massacres and displacements in West Sudan. We could not really make sense of that, as we are not Sudan specialists. They initially even reported that this was a conflict between Christians and Muslims etc.- - until we received detailed studies from Human Rights Watch and Global Witness that described this as a war of expulsion [Vertreibungskrieg]" (author's translation).

The pattern of his and his paper's publications about Darfur unfolded during the first half-year of reporting as follows:

- Io/28/2003: AP report based on USAID information (I07 words)

- II/I4/2003: overview article by colleague of interviewee based on UN sources (36I words)

- I2/22/2003: article by interviewee on the North-South agreement mentioning Darfur (340 words)

- I/28/2004: article by interviewee on violence and settlement efforts, partly based on press agency reports (38I words)

- 2/IO/2004: article by interviewee on violence and Darfur refugee crisis in Chad, based on UN and Chadian government sources (26I words)

- 3/20/2004: Evangelischer Pressedienst (EPD) agency report on single attack ( 83 words)

- 3/23/2004: article by interviewee on violence and government of Sudan's denial, based on UN sources ( 345 words)

- 4/7/2004: article by colleague of interviewee on the aftermath of the Rwandan genocide, including a paragraph on Darfur, citing UN sources and HRW (I,077 words)

- 4/10/2004: Deutsche Presse-Agentur (DPA) report on truce (7I words)

None of these articles appeared in the paper's most visible places, but this soon changed when, on April 23, 2004, the Darfur conflict actually advanced to the paper's front page. It featured an article by the interviewee entitled "Alarming Report of the United Nations: Mass Murder and Atrocities in Sudan" (Alarmierender Bericht der Vereinten Nationen: Massenmorde und Gräueltaten im Sudan) (593 words). The article was accompanied by an opinion piece on page 4 (225 words) 
and an "external report" on page 2 (963 words), the latter written by a former minister of justice who was then a UN special rapporteur on human rights in Sudan. The lead article referred to a not-yet-published report by the UN high commissioner for human rights: "The report charges the Government of Sudan and a closely allied militia with war crimes. There is said to be a 'domination of terror' [Herrschaft des Terrors] in the crisis region of Darfur, with ethnically motivated mass murders, rapes and evictions. The regime in Khartoum thus far refuses to allow the UN any access to the region" (author's translation).

The author-interviewee explained:

And we had the report. And then we were the first newspaper in all of Europe, I believe, that wrote about the Darfur conflict in a lead article on page I. That found much resonance, also, in other media. This report was then also given to other newspapers, of course. ... That developed its own dynamic, also because then I traveled with the colleagues [from other papers] to Chad, for example, to tour the border areas and visit refugee camps, gaining an understanding of the situation there. (author's translation)

Communication between the paper's foreign editor and a high-ranking politician with access to a repressed UN report had opened the path for this front-page reporting. My interviewee received permission to travel to Chad to investigate, and his contributions (and those of others) soon appeared in rapid succession: May 27 (article and editorial), May 28 (article by a colleague), May 29 (DPA), June I (by colleague and DPA report), June 3, June 5 (by colleague), June $\mathrm{I}_{4}$ (article and editorial), and June I9 (by colleague). Such intensification of reporting was not unique to this paper, but part of what became a flood of journalistic interest in Darfur. This flood crested at the peak of reporting in 2004 as depicted in figure 2I. This story of one paper's entry into reporting about Darfur illustrates how communication between a paper's leadership and a high-ranking and respected politician helped bring Darfur to the front page and assure the paper's correspondent a travel permit into the crisis region. There is every reason to believe that this paper's story is representative of others.

The 2004 peak of reporting was followed by a modest but nonetheless noticeable drop in 2005 in all eight countries. This decline, however, did not reflect a lack of events to report on. The ICID issued its report in January. In May the UNSC referred the case to the ICC. Meanwhile in the United States the Save Darfur coalition began to gather steam. The violence continued in Darfur, albeit at a level well below the peaks of mid-2003 and early 2004. Yet neither did the killings cease, nor did 
the suffering of the surviving population diminish. An epidemiological study finds: "The number of internally displaced persons remained constant, but the number of affected residents tripled; the increase in humanitarian aid was similar to the increase in total number of people affected, resulting in a constant ratio of 40 humanitarian aid workers to I00,000 people affected" (Degomme and Guha-Sapir 2010:296).

After 2005 , reporting increased again, reaching a second peak in 2006 in six of the eight countries. It started to drop off in only two countries after 2005. What may have motivated this intensification in reporting about Darfur? Might events on the ground in the crisis region have ignited renewed interest? Again, public health researchers who reported on the state of the Darfuri population inform us that, between the middle of 2006 and late 2007 , "because of insecurity, the number of internally displaced people increased by about 40\% (from I, 7 I 7,092 to $2,387,594$ ); concomitantly, and partly as a result of reduced funding, the number of humanitarian aid workers decreased from I 4,75 I to I 2, I I 2 by July, 2007 (i.e., 29 aid workers for every Io0,000 people affected)" (Degomme and Guha-Sapir 2010:296). Insecurity intensified, especially when in May 2006 the DPA was signed but failed to bring peace, and this setback was followed by a new offensive by the Sudanese military in August 2006. Although events on the ground did not initially spark media attention, this time they were accompanied by political and civil society actions, especially in the United States.

There, in October 2006, President Bush signed into law the Darfur Peace and Accountability Act (House Resolution 3 I 27/Senate Bill I462). The act confirmed the administration's position that the violence in Darfur constituted genocide. It also instructed the government to assist the ICC in its pursuit of the responsible actors-despite the United States' continued refusal to ratify the Rome Statute. This signing into law was preceded by a massive Save Darfur demonstration in Washington in April 2006 (see chapter 3). While these domestic US events may have contributed to an increasing volume of American media reports, it is unlikely that they had an equal impact in raising the number of media reports in the other countries. Instead, global action is more likely to have intensified attention across countries. Such action included the February 2007 application for and the April issuing of an arrest warrant against Ahmed Harun and Ali Kushayb at the ICC, and passage in July 2007 of UNSC Resolution I769, authorizing the establishment of UNAMID, the UN-AU hybrid peacekeeping mission for Darfur. 
Figure 2 I shows further that the second peak in the intensity of reporting, registered in 2007 , was followed by a massive and steady decline in each of the subsequent three years. By 2010, the number of reports was barely above the minimal level of 2003 reporting. This decline occurred despite continued suffering in Darfur. The public health study cited above reports that from October 2007 through December 2008, the beginning of the steep decline in reporting, the "number of internally displaced people" continued to increase (Degomme and Guha-Sapir 20I0:296). Apparently even international responses could not prevent the decline. Among these responses were the ICC's unprecedented and much debated steps in 2008 and 2009. On July I4, 2008, the Office of the Prosecutor applied for an arrest warrant against Omar al-Bashir, the sitting president of Sudan. The application was based on charges of war crimes, crimes against humanity, and genocide. On March 4, 2009, the court issued the arrest warrant for war crimes and crimes against humanity. Following this decision one Abu Garda, a lower-level rebel leader made a first appearance before the ICC, on May I8, 2009, and in 20I0-beyond our observation period-the court issued the arrest warrant against al-Bashir for charges of genocide. ${ }^{5}$ In short, the suffering on the ground and ICC actions were substantial. And yet, reporting declined precipitously.

Interviews suggest several potential explanations for the decline in reporting. Respondents point at constraints imposed on journalism by both the economic and political fields. One crucial part of journalism's political environment, an issue throughout the Darfur conflict but intensifying over time, was the government in Sudan. A German Africa correspondent spoke about difficulties in obtaining visas for Sudan from his seat in Nairobi. A British journalist reported that during his MayJune 2004 visit to Sudan he waited "much of the month" in Khartoum before receiving travel permits to Darfur. The same journalist decided later in the year to travel to Chad to avoid the political-bureaucratic hurdles set up by the government of Sudan. Another British journalist similarly reported having been stuck in (expensive) Khartoum for "a couple" of weeks before receiving a permit to travel to Darfur. Rob Crilly (20I0), a British Africa correspondent who reported extensively from Sudan, including Darfur, provides a lively illustration:

It felt good to be in Khartoum at last. For a year I had potted back and forth to the Sudanese embassy in Nairobi enquiring as politely as I could whether my visa was ready for collection. . . . But arriving in Khartoum was just the start of the journey to Darfur. Each foreigner has to first register with the Police 
Department of Aliens. . . . After the Department of Aliens came the Department of Foreign Correspondents and Journalists. . . . Now came the tricky part of obtaining permission to work as a journalist-filling in the "Purpose of Visit" section on my application for a press permit for Darfur. . . . But how to phrase "reporting on genocide" in a way that would be acceptable to the very regime responsible? (7-9)

Needless to say, none of these bureaucratic hurdles was easy to surmount. And, once journalists succeeded in accessing the field, their mobility was further inhibited. ${ }^{6}$ These challenges to journalistic work, imposed by the government of Sudan and its bureaucrats, prevailed throughout the reporting period. After 2007 Khartoum imposed even further restrictive policies on foreign journalists, thus likely contributing to the massive decline in reporting. In the words of a Swiss interviewee: "Today Khartoum barely allows any journalists to go there" (Heute lässt Khartoum ja kaum noch Journalisten dahin).

Gaining direct access to the field, a challenge in reporting on any conflict, was not the only impediment that worsened. Common sources of information also dried up. Some aid agencies, including three sections of MSF, were evicted, especially after the indictment of al-Bashir, as noted in chapter 4 . In addition, aid agencies became ever more cautious in light of the risk of being denied access to the populations in need. After all, evictions were partly based on claims by the government of Sudan that aid agencies had abandoned their commitment to neutrality norms and were supplying the ICC with information on which charges could be based. ${ }^{7}$

Denial of access by the government of Sudan and the drying up of sources of information are obviously weighty factors in any attempt to explain the drop-off in reporting about Darfur after 2007. But they are to be supplemented by forces associated with the journalistic market for information. ${ }^{8}$ These market forces are best captured in an interview with a German Africa correspondent who discussed stalemates in the decision-making bodies of the international community:

This Darfur conflict, however, quite decisively disappeared from public view, because-I believe-there emerged an absolute stalemate. [In the UNSC t] he Americans could thus scream, the Europeans could scream, and the Chinese said "no" and the Russians too. Then you realize that there is simply no way forward, and the only thing that still caused attention was that they issued this international arrest warrant against Bashir. But that is totally personalized and focused on one single person. What's going on in Darfur these days is barely being registered, neither by the public nor by journalists, because it is redundant in the end, because it has been happening for years. (author's translation) 
It is not surprising that dramatic events are especially appealing in the media market. It was thus unfavorable for journalistic attention that after 2007 the situation on the ground in Darfur showed no major change and that the international community was partially deadlocked. Demands by consumers of news media obviously matter, especially among market-driven media, and this pattern is not unique to reporting about violent conflicts. ${ }^{9}$

In short, the trend line of reporting about Darfur in prominent Western newspapers reflects the impact of market and political forces on the journalistic field. On the one hand, initial journalistic attention and a massive increase in reporting about Darfur proved to be inspired by the political field. Western politicians and the UN played an important role, while actors from the human rights field provided additional support. This causal path does not always apply, of course. Sometimes journalists report from crisis regions for extended periods without being alerted by political actors-and without finding any resonance in the political sphere. The second wave of violence in Darfur coincided with the symbolically laden tenth anniversary of the Rwandan genocide. In addition, the United States experienced a massive civil society mobilization after several American carrier groups, especially evangelical Christians, Jews, and African Americans, identified with victims of the violence and sparked a mobilization that provoked relatively forceful rhetoric among political leaders. On the other hand, the always present restraints that the government of Sudan imposed on journalists intensified with the growing international responses to the conflict. In addition, the flow of information from aid agencies dried up in response to pressure from the authorities in Khartoum. These observations speak to recent scholarship on the mediatization of politics. Yes, the logic of the media field may at times influence political actors, organizations, and institutions (Strömbeck and Esser 20I4), but cautionary notes highlighting reverse effects of the political field on journalism are also supported (Mazzoleni and Schulz I999). Such caution is all the more valid whenever authoritarian regimes are involved.

Finally, political pressures coincided with economic forces within the media market. The cycle of news reporting, with its focus on the new and dramatic, enhanced the decline in media attention about the ongoing suffering in Darfur. The decline would likely have been even more abrupt had the ICC not intervened. Judicial interventions helped keep the media's attention on the conflict, though not at the high level of earlier stages. But how specifically did juridical forces act on the 
journalistic field? If they could not prevent the decline of attention, could they affect the substance of reporting? What were their opportunities and constraints? What cultural receptivity did they encounter?

THE JOURNALISTIC FIELD, THE JUDICIAL FIELD, AND THE LEGAL COLORING OF REPORTS

The journalism and judicial fields, both semiautonomous, are reciprocally related. Not only do they affect each other-through regulation in one direction, for example, and through issue selection and editorial support in the other-but they may even interpenetrate. Remi Lenoir's (I994) Bourdieuian analysis, for example, diagnoses intrusions of journalism into the legal field similar to those Bourdieu described by which media logic shapes the political field. Lenoir refers to the well-known case of "tough" judges who use mass media to advance their reputation and, by doing so, change power relations within the judicial field. Juridical criteria subsequently lose ground in legal decision making to populist sentiments and media concerns, and the judicial field thereby loses relative autonomy. Arguments about the mediatization of politics (Strömbeck and Esser 20I4) may thus also apply to the judiciary. In reverse, the judicial field may strengthen its position vis-à-vis other fields, including that of journalism. Michael Kearny, at a 20 I I Vassar Institute conference on war journalism held in The Hague, showed how war reporting is increasingly permeated by the language of human rights and international law, often at the expense of political analysis. This trajectory from political to legal categories proceeds by means of diverse mechanisms, among them NGO informants who, in Kearny's words, "hijack the language of law" or seek to "mainstream the language of human rights." ${ }^{\text {1о Kearny's }}$ argument is reflected in the sentiments of several interviewees. Diplomats and NGO specialists with a political science background charged that legal language endangers a political understanding of mass violence. Relatedly, Pendas's (2006) analysis of the Frankfurt Auschwitz trial, cited in greater detail in chapter 8 , shows how rules of the journalistic game, especially the objectivity rule, contribute to a literal transmission of courtroom events through media reporting to a broad public. As a result, historical truth is overshadowed by judicial truth. Trials, and media reporting on them, focus attention on individuals, their criminal intent, and atrocities. The bureaucratic nature of the murder machine and its political context are almost lost from sight (see also Marrus 2008; Savelsberg and King 20II). 
Both interviews and patterns revealed by the Darfur media data set speak to the relationship between journalism and the judicial field. The data provide a more mixed portrait than that suggested by opposing strands in the literature on media and law. In line with the statements quoted at the beginning of this chapter, Africa correspondents generally reported a substantial disconnect from the court. A German interviewee from Nairobi told me that he had never been to The Hague. Similarly, a British respondent claimed not to have received any information directly from the ICC. He learned only about special events such as indictments-and only from sources other than the ICC. An Irish journalist confessed that he knew about the ICC and its actions primarily as a newspaper reader. Yet another interviewee told me that information he received about big events at the ICC was based on wire reports. $\mathrm{He}$ added that it was always easy to slip a sentence about a wanted war criminal into an article. Other journalists, by contrast, did report interactions with the court. Yet they experienced conditions in the judicial field not compatible with their journalistic habitus. The journalist quoted at the beginning of this chapter as denying that the ICC was in any way an information source for him continued:

I had occasional contacts with investigators for the ICC, but that was in the context of the Congo, East Congo, and the DFLR [Forces Démocratiques de Libération du Rwanda], those Rwandan militias, and how they acquire funding. These people wanted information from me. I am a journalist. I told them, "One hand washes the other. You can get something from me, give me something of yours, and then we can talk reasonably in whatever way that can be published at all without endangering your work." I never heard from them again. But it would be interesting to learn how often the term International Criminal Court is now being used in media reporting. Very often. At the same time we know that those who report about it know nothing about this criminal court, because this court shuts itself off. That is a pity. (author's translation)

This statement illustrates how not just geographic distance between Africa correspondents and the ICC, but also a different habitus and contrasting rules of the game impede communication. The journalist's tit-for-tat practice does not work in interactions with those bound by judicial rules. Another interviewee, an Africa correspondent who works out of the capital city of his European country, noted additional communicative hurdles: "I've been there [ICC in The Hague] once. And it was useless, in fact. . . Their time is not our time. It is not the same. ... It is years." The journalist here contrasted the slow progress of judicial 
proceedings with the fast pace of journalistic work. Journalists also need to explain to domestic readers the institutional particularities of an international court. "We have the problem," the same correspondent pointed out, "that the judicial system used in The Hague is not the French one. So we have to explain to people how it works." This journalist observed that usual translation issues with turning "legalese" into everyday language gain urgency when international courts are the issue: "It is a big part of our job as a journalist, not understanding something and trying to find someone who can explain. ... I've got a friend who is working for Human Rights Watch. She is focused on just this, on the ICC." This statement illustrates not only an impediment faced by journalists who wish to report about the international court but also a mechanism through which human rights activists may affect media reporting: as translators of international human rights law for use by journalists. This observation adds a significant component to the importance that Africa correspondents in the field attribute to INGOs as informers.

In short, Africa correspondents have little interaction with the ICC, and the interaction they do have is marred by problems. But they are not the only contributors to journalistic work about Darfur. A German Africa correspondent referred me to a colleague who worked from his paper's headquarters and, while not an Africa specialist, did visit the courts. Similarly, a US journalist mentioned her paper's specialist for institutions such as the ICC, who occasionally supplied her with relevant information. One interviewee who covered international organizations from her European capital city spoke about an upcoming trip to The Hague. Finally, a British correspondent reported, and his foreign editor confirmed, that the paper would send someone to The Hague "for the big day." And such "big days" indeed find many journalists gathered in the ICC's pressroom (see figure 22).

Given these conditions of reporting and the ambivalent role of the ICC in its relation to journalists, how do judicial interventions affect media representations of Darfur? Our data demonstrate that several intervention points-but not all-are intensely reflected in journalistic reporting. Figure 23, for example, displays the percentage of articles about Darfur per time period that cited the crime frame in combination with three competing frames. The graph shows that increases in use of the crime frame followed the release of the ICID report, the ICC prosecutor's application for a Darfur-related arrest warrant (against Harun and Kushayb), the application for an arrest warrant against al-Bashir 


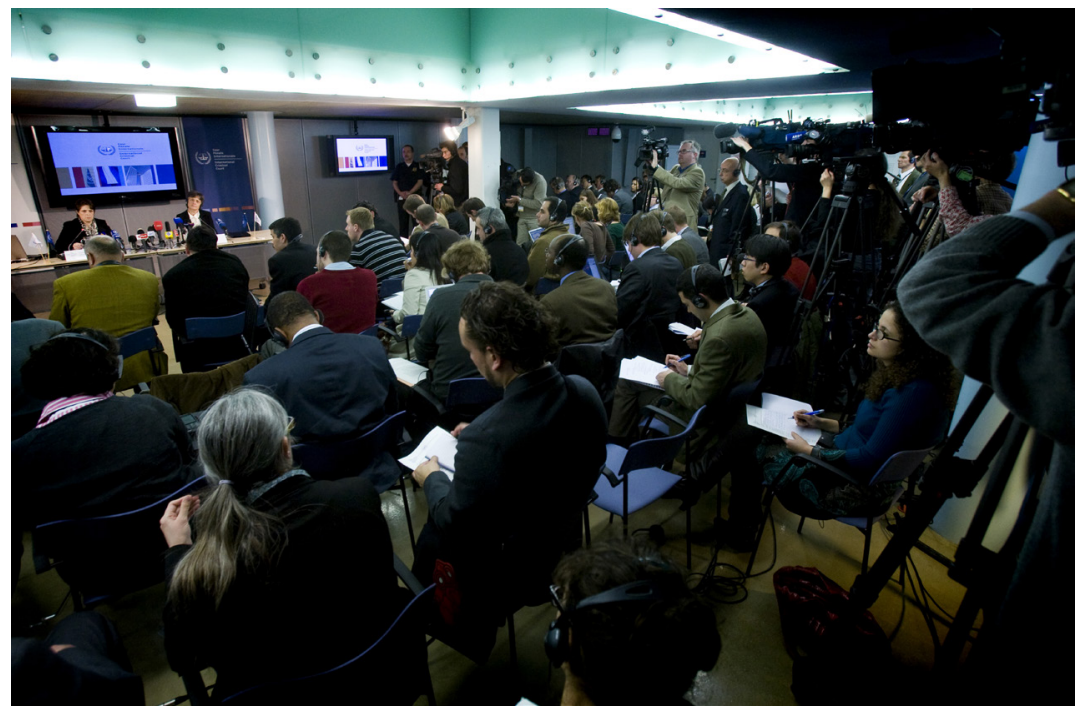

FIGURE 22. Press conference in the press room of the International Criminal Court, The Hague.

(the rather high level persisting after its issue), and finally a first court appearance of an accused. The crime frame lost ground during the periods marked by UNSC Resolution I 564 (establishing the ICID) and the UNSC's referral of the Darfur situation to the ICC. We shall see below that the latter action was followed by a major diplomatic event (signing of the Abuja Peace Treaty), the leadup to and aftereffect of which appear to have overwhelmed uses of the crime frame. Reporters favored instead the use of the civil war frame during this period, as the respective lines in figure 23 indicate. Another drop in the use of the crime frame, this time surprising and unexplained, occurred after the ICC issued the first major arrest warrants (against Harun and Kushayb). In the following I first focus on the crime frame and afterward return to the alternative and potentially competing frames.

References to particular types of violence and crime, specifically killing and rape, peaked, albeit in less pronounced ways, at the same stages at which the crime frame was cited most frequently (figure 24): the release of the ICID report, the prosecutor's application for arrest warrants against Ahmed Harun and Ali Kushayb, and the application for and the issuing of an arrest warrant against President al-Bashir. The reporting of destruction of livelihood and displacements, in contrast, showed steady declines barely interrupted by judicial interventions. 


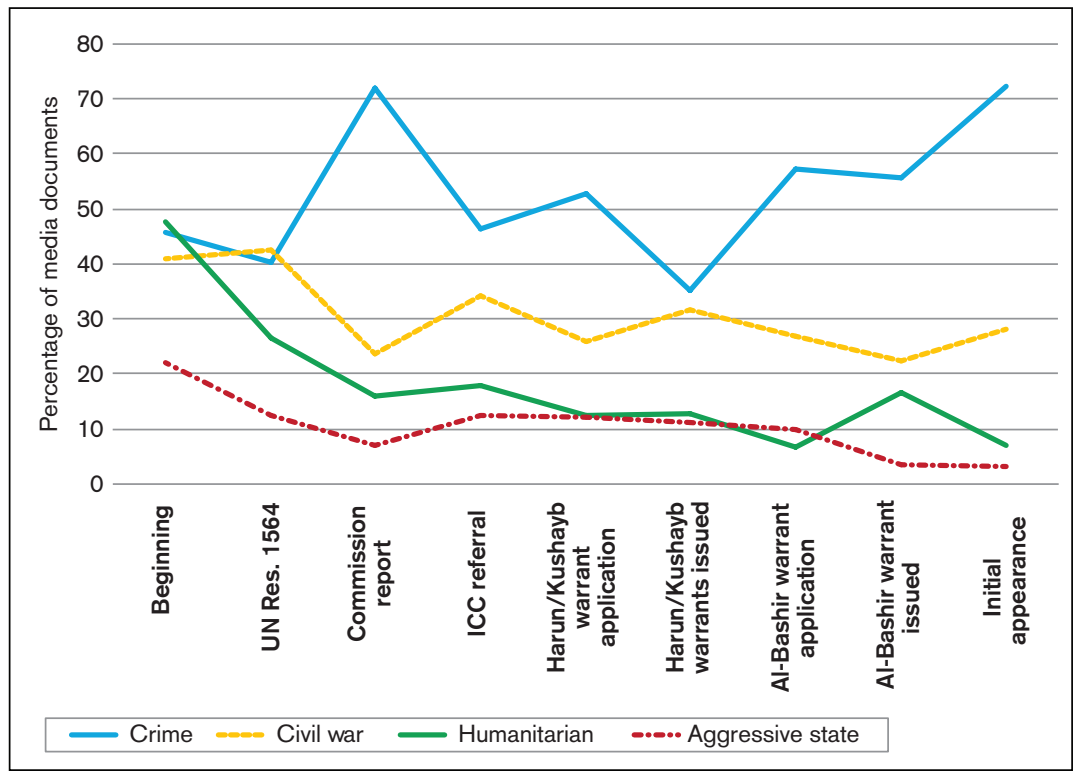

FIGURE 23. Percentage of newspaper documents on Darfur using the crime, civil war, humanitarian emergency, and aggressive-state frames, by time period.

Modest exceptions are minor upticks in reporting the destruction of livelihood after the release of the commission report and the charging of al-Bashir, as well as in reporting about displacements after the issuing of arrest warrants against Harun and Kushayb.

What exactly does the changing intensity of applying the crime frame and of reporting specific types of victimization mean, and how can it be explained? The first major peak in citations of the crime frame followed the release of the ICID report in January 2005 (figure 23), and was paralleled by a peak in intensity of reporting about killings and rapes (figure 24). This may not be surprising, as the commission had cited instances of war crimes and crimes against humanity (but not genocide). Thus, not only did all papers intensify reporting about Darfur after February I, 2005, the day of the report's release to the public, as we saw earlier, but they also now stressed the crime frame and reminded readers of the suffering of the population. An article written by Warren Hogue of the New York Times (2/I/2005) illustrates how a US paper described the ICID report to its readers: "A United Nations commission investigating violence in the Darfur region of Sudan reports Monday that it had found a pattern of mass killings and forced displacements of 


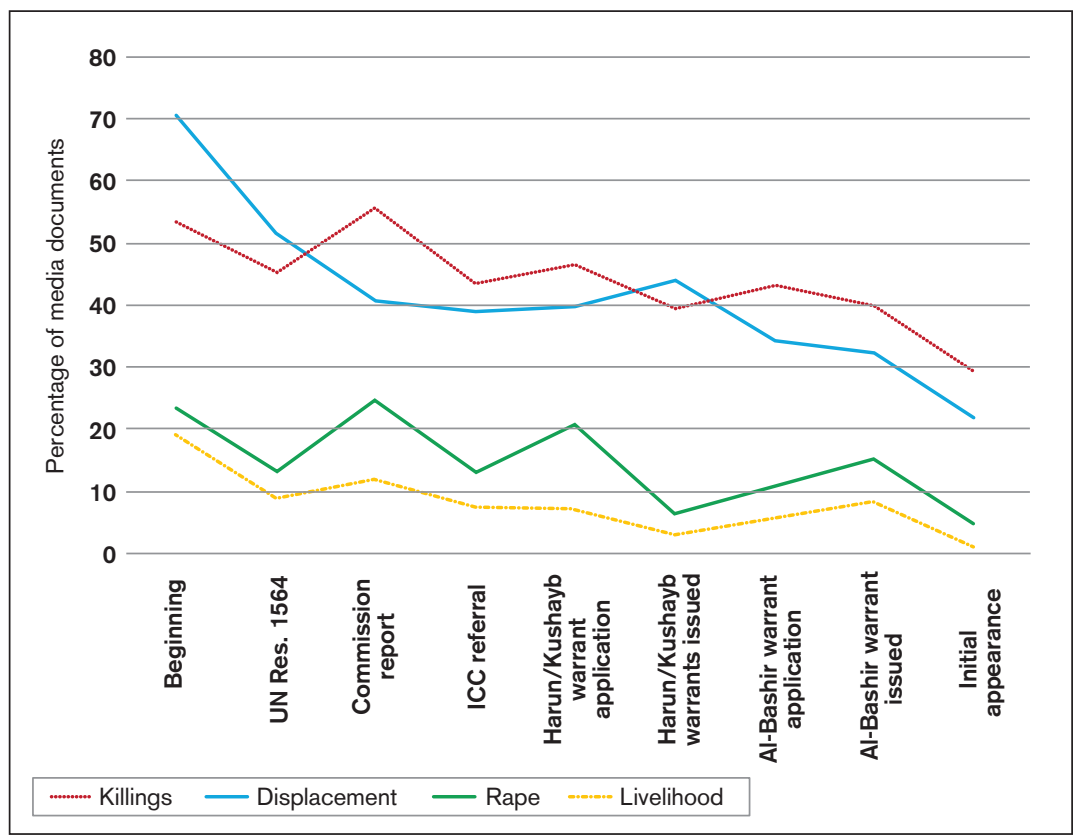

FIGURE 24. Percentage of newspaper documents referencing different types of suffering, by time period.

civilians that did not constitute genocide but that represented crimes of similar gravity that should be sent to the International Criminal Court for prosecution" (p. 3).

The article was followed, on February 2, 2005, by an op-ed by Nicholas Kristof entitled "Why Should We Shield the Killers," critiquing the initial inclination of the Bush administration to challenge a UNSC referral of the Darfur situation to the ICC. Also on February 2, 2005, Lydia Polgreen of the NYT wrote an article headlined "Both Sides of Conflict in Darfur Dispute Findings in U.N. Report." On February 9, 2005, Warren Hogue reported again, this time about Sudanese attempts to prevent international prosecution. On February I0, 2005, Samantha Power, then a "lecturer at the Kennedy School of Government at Harvard," used an op-ed in the NYT to offer strong support for the ICC as a "court of first resort" and for a referral of Darfur to the court. The paper's February II, 2005, edition featured the following "quotation of the day," which it attributed to "Mohammed": "We will take care of the child. It is very difficult to love a janjaweed, but we will try to accept him as one of our own.' MOHAMmed, whose sister Ashta gave 
birth after being raped by a janjaweed militia fighter in Darfur, Sudan.” More than a dozen articles and editorials followed in the remainder of February 2005 , supplemented by numerous letters to the editor.

Other in-depth journalistic examinations are telling. As a first example, one of the prominent German papers, the Süddeutsche Zeitung, featured, on February 2, 2005, an article by Arne Perras about the ICID report. The article, entitled "Crimes in Darfur: The United Nations Charge the Sudanese Power Holders [Machthaber] and Demand They Be Punished" and "The Masters of the Death Riders" [Die Herren der Todesreiter], included this summary: "A UN report proves that the government in Khartoum positioned the militias in West Sudan" (author's translation). Another dozen articles followed in the $S Z$ in February alone. Those that included opinions expressed clear support for a referral of the case to the ICC. In France, on February 2, 2005, Le Monde reprinted segments of the commission report under the headline “'Action Is a Matter of Urgency': The UN Does Not Determine Genocide but Denounces Crimes against Humanity in Darfur" (author's translation). On the same day, correspondent Corine Lesnes contributed a lengthy report on the commission's conclusions. Some ten articles followed in February. In the United Kingdom, the Guardian's February I, 2005 , report by "diplomatic editor" Ewen MacAskill was entitled "Sudan's Darfur Crimes Not Genocide, Says UN Report." But MacAskill followed up on February 2, 2005 with a piece headlined "Sudan Risks Sanctions as UN Lists Atrocities." The editorial begins: "The Sudanese government could be hit by UN sanctions after the publication yesterday of a 244-page report on the Darfur crisis which detailed horrific and widespread crimes against humanity, including the systematic use of rape as a weapon of terror" (p. I 5 ). The number of subsequent articles was smaller than in the other papers, while several reviews of the film Hotel Rwanda built bridges between the Rwandan genocide and events in Darfur. On February 16, 2005, for example, Africa correspondent Jeevan Vasagar, writing from Kigali, quoted Paul Rusesabagina, the former manager of Mille Collines (the real-life model for Hotel Rwanda), as saying at the time of the genocide: "What happened in Rwanda is now happening in Darfur, in the Congo, in all of these places they are butchering innocent civilians" (p. 3 ). ${ }^{\text {II }}$

For a second example, consider the rise in the number of crime frame citations after the Office of the Prosecutor applied for an arrest warrant against Sudan's sitting president, Omar al-Bashir (figure 23). Use of the crime frame stabilized at this new, high level after the warrant 
was issued, and it increased further in the final reporting period, after the initial appearance of a rebel before the ICC. Again, a closer look at patterns of reporting in specific media sheds light on the meaning of this peak.

In the United States, the New York Times featured on July I 5 , 2008, one day after Moreno-Ocampo's application for an arrest warrant against al-Bashir, a long report by staff journalists Marlise Simons (Paris), Lydia Polgreen (Dakar), and Jeffery Gettleman (Nairobi). Their I,446-word article reviewed the mass violence in Darfur. It also reminded the reader of Slobodan Milošević and Charles Taylor, two previous sitting presidents who had been tried before international tribunals. The authors further quoted chief prosecutor Moreno-Ocampo: "Mr. Bashir had 'masterminded and implemented' a plan to destroy three ethnic groups. ... Using government soldiers and Arab militias, the president 'purposefully targeted civilians'" (p. r). An editorial of the same day, entitled "Charged with Genocide," opens with this sentence: "The truth can be difficult. That doesn't make it any less true. And so we support the decision by the prosecutor of the International Criminal Court to bring charges of genocide against Sudan's president, Omar Hassan al-Bashir, for his role in masterminding Darfur's horrors" (NYT 7/I 5/2008, p. I 8). Also on the same day, an opinion piece by Richard Goldstone, former chief prosecutor of the ICTY and ICTR, strongly supported the arrest warrant against al-Bashir. Both the editorial and Goldstone's piece challenged critics who pointed at an indictment's problematic consequences for aid delivery and diplomatic efforts. Some twenty additional articles and editorials follow in the New York Times in the remainder of July 2008 alone. The editorials uniformly supported the prosecution.

But attention to the prosecutor's decision to charge al-Bashir and to the crimes committed in Darfur does not necessarily imply a paper's support for the prosecutor. The German Frankfurter Allgemeine Zeitung may serve as an example. Following the date of the application, July I4, 2008, the FAZ published a flood of articles, beginning with an 883-word front-page report on July I 5 entitled "Arrest Warrant against Sudanese President Applied For: Prosecutor at Criminal Court Charges al Bashir with Genocide in Darfur." (author's translation) The article was accompanied by a front-page editorial by editor-in-chief Günther Nonnenmacher entitled "Law against Violence" (Recht gegen Gewalt). Nonnenmacher expressed sympathy with those who welcomed the pending prosecution, and spelled out the suffering al-Bashir 
had brought to so much of his country. Although he clearly did not deny that violence and suffering had occurred, he sympathized with critics of prosecution and their political objections. He wrote about inadequate attempts to compensate for political failure by judicial means, and he anticipated that the situation on the ground would deteriorate as a consequence of the prosecutor's action. Comparable to the number of items in the New York Times, in the remaining two weeks of July, the $F A Z$ published almost twenty more reports and editorials following these first items.

In the wake of the prosecutor's decision to charge al-Bashir, the FAZ's attention thus clearly returned to Darfur, and the criminal nature of the violence was confirmed. Yet Nonnenmacher's editorial critique did not appear in isolation. Several subsequent pieces expressed doubt about the political wisdom of prosecution. For example, a July 20, 2008, article by Hans Christian Rössler was entitled "Rather Vote Out of Office [Lieber abwählen]: Even Some Opponents of Sudan's Head of State al Bashir Do Not Approve of the Arrest Warrant against Him" (author's translation). A July press agency report published in the FAZ cited doubts against the prosecutions expressed by Amr Mussa, president of the Arab League. A brief piece by Rössler on July 22 was entitled "Peace Process at Risk: Sudan Warns against Charging Bashir" (author's translation) A book review on July 23 discussed Harald Welzer's work on the ecological causes of violence, reflecting one of the arguments that opponents of criminalization had previously used to challenge judicial responses. And on July 28 an article by Rössler, "Risks of Failure in Sudan" (author's translation) warned that prosecutions would endanger the North-South process.

In short, comparing reporting and commentary in the NYT and the FAZ sheds light on the meaning of peaks in crime frame citation frequency. First, ICC interventions refocused the world's attention on the violence in the conflict zone. Second, the criminal nature of the violence was confirmed. And third, refocused attention and use of the (diagnostic) crime frame was in some cases associated with support for the prosecutor's decision-but with challenges to judicial responses in others. Strategies deemed appropriate against criminal violence thus may or may not correlate with the use of the crime frame. The (prognostic) frame, referring to preferred solutions, may well not be aligned with the diagnostic frame, and it is indeed not aligned in reporting about Darfur by papers such as the $F A Z .{ }^{12}$ 
THE JOURNALISTIC FIELD, THE HUMANITARIAN FIELD, AND THE COLORING OF REPORTS

Descriptions of $F A Z$ reporting following the application for an arrest warrant against President al-Bashir reveal that news media that cite the crime frame do not necessarily support criminal justice interventions. While acknowledging the criminal nature of the violence, such reports may nevertheless highlight the need of mediation or military intervention. At other times media recognize violence as criminal but opine that aid should trump justice in the light of human suffering. In the statement quoted above, Günther Nonnenmacher from the $F A Z$ even sympathized with the call for justice, but he eventually pleaded against penal responses in anticipation of a deterioration of the humanitarian situation on the ground and challenges to the peace process as a consequence of an indictment against al-Bashir.

Previously we encountered skepticism toward the judicial field in humanitarian aid organizations. Chapter 4 on MSF provides manifold examples. It is not surprising, given the relationship between the humanitarian and journalistic fields analyzed above, that such skepticism is reflected in media reports. Interviews with humanitarian NGO experts reveal their often close contact with correspondents in crisis regions, for example, as hosts in relatively safe compounds within often challenging natural and social environments. Likewise, journalists also report about their contacts with humanitarian NGOs. For instance, both German correspondents I interviewed listed aid organizations as important sources of information. One mentioned MSF in particular (as did an American journalist). Three British journalists referred to either aid agency reports, humanitarian organizations on the ground, or just INGOs as crucial sources of information. One French journalist told about NGOs based in Chad whose representatives served him as crucial informants. He too mentioned MSF by name. Another French correspondent also referred to MSF, not incidentally when she stressed her paper's avoidance of the term genocide, in line with MSF policies. Here the policy and framing of an aid organization corresponds with journalistic vocabulary, and may have inspired it. ${ }^{\mathrm{I} 3}$

Despite the centrality of aid NGOs as sources of information, however, citations of the humanitarian emergency frame, as figure 23 shows, faded compared to uses of the crime frame. While they started 
at the same high levels, making an appearance in almost every other article published in the initial period, references to the humanitarian frame dropped to below 30 percent in the second period. They declined further to between so and 20 percent in the later periods. What might explain this rapid decline in the number of humanitarian representations to a relatively low level? Evidence suggests that here, too, media markets and political forces are causal contributors. We know that the government of Sudan evicted humanitarian NGOs from Darfur, including three sections of MSF, as early as 2007 and as late as 20I4. Those who remained grew cautious in their statements to the news media (and to the court). The actions of the Sudanese state thus likely contributed to declining use of the humanitarian frame in media reports. In addition, a humanitarian emergency is a state more than an event. It lingers. It is news for a brief period, after which it becomes old information and thus of little value in media markets.

Yet some newsworthy events do occur in the humanitarian realm. Consider the release of spectacular reports by INGOs such as the oftencited Amnesty report on rape and the two MSF reports "No Relief in Sight" and "The Crushing Burden of Rape." Release of "No Relief in Sight" coincided with an extraordinary opportunity to reach a world audience. In the words of one MSF interviewee:

Well, I was the crisis communications manager in June and July in Khartoum, Darfur, and Paris. And this was right at the moment when we released epidemiological data. . . . The actual press release that I helped write in the field with the president of MSF-France and the head of mission was called "No Relief in Sight." ${ }_{44}$ And it accompanied an epidemiological report. And the basic premise of that was to say, "Without a massive humanitarian response lots of lives would be lost." ... And Colin Powell came to visit Khartoum. ... [The respondent was in Murnei refugee camp in West Darfur,] and there was a big scramble to get me back to Khartoum because there was going to be the entire press corps, following with Colin Powell. And I remember coming into the press room, just walking from one person to the other and handing out our press release, the "No Relief in Sight." And I believe it was quoted in a lot of those initial stories.

Is the MSF staffer right in his perception of the effect of the news release? The document is dated June 2I, 2004, and the opportunity to distribute it to the press corps following US secretary of state Colin Powell's visit offered itself on Wednesday, June 30. A look at our newspaper data does show intense media attention to Darfur around these dates. On July I, 20I4, the NYT featured a front-page article on the situation 
in Darfur. Earlier, on June 24, the Swiss Neue Züricher Zeitung had reported on a visit of the Swiss foreign minister to Sudan, including its refugee camps. In portraying the violence, the paper did cite the MSF report: "No one knows exactly how many civilians were killed by the Janjawiid. One probably has to assume several tens of thousands of dead as a minimum. This conclusion is suggested by a survey that Médecins Sans Frontières conducted in the refugee camps of Murnai and Zalingei in West Darfur-the most comprehensive study of this kind thus far" (author's translation). Information about the methodology of the survey leads the journalist to conclude: "Should this percentage be representative of the entire rural population of Darfur, then we would calculate a number far above 120,000 dead. To be added to those are the persons who now perish in the refugee camps, because the government restricts the delivery of urgently needed aid" (author's translation). For the remainder of June, I found one more reference to MSF, but not to the report itself.

In the United Kingdom, the Times of London featured Secretary Powell's visit in an article of July I, 2004. The report recounted the history of violence and suffering in Darfur without, however, citing the MSF release. The Times' left-liberal competitor the Guardian, however, featured a lengthy June 25 article authored by Jeevan Vasagar entitled “There Is No Hunger Says Sudan As Children Die." It was reported from Khartoum and from the Murnei refugee camp, from which my interviewee rushed to Powell's press conference just a couple of days later. From within the camp, Vasagar reported about an MSF feeding center, and cited MSF president Jean-Hervé Bradol's grave accusations against the government in Khartoum for impeding the delivery of aid.

In France on June 25, 2004, Le Figaro featured an 804-word article on the violence in Darfur. The report, entitled "Darfur under the Pain of Hunger and 'Arab Cavalries [cavaliers arabes]'" (author's translation), cites MSF, though without mentioning the specific report. No other Figaro piece in June returned to any MSF source. Le Figaro's left-liberal competitor Le Monde paid closer attention. On June 25 it featured a detailed report by its staff reporter Jean-Philippe Rémy. The article's title is a quotation of MSF's Jean-Hervé Bradol: "Khartoum has maintained a ferocious repression on Darfur" (Khartoum a mené une repression féroce au Darfour). Another piece on June 25, published under the same title, summarized the events and provided a count of 
those killed and displaced. Almost a half-dozen articles followed in the final days of June and at least one, a June 30 article on Colin Powell's visit, again cited patterns described by MSF.

Other papers too reported about Darfur on the days following the report's release and Colin Powell's visit, and several of these cited the MSF study. Clearly, the INGO's campaign was reflected in the world press. Reports like "No Relief in Sight" in all likelihood contributed to the substantial media attention in mid-2004. They helped advance the humanitarian crisis frame in the early stages of reporting. Yet they neither prevented the decline in reporting nor did they secure the application of the humanitarian emergency frame in the long run. This finding is all the more remarkable as the MSF press release was part of a flood of pronouncements during the summer of 2004. Both Colin Powell and Secretary-General Kofi Annan visited Sudan and Darfur and addressed the humanitarian catastrophe. Many other aid organizations were active and spoke up as well. A report from the German Evangelical Press Service (EPD), published on the front page of the FAZ on June 28,2004 , and supplemented by a report on page 6 by Thomas Scheen, the paper's Africa correspondent, makes this point quite clear: "The assistant foreign minister [Staatsministerin im Auswärtigen Amt], Kerstin Müller (Green Party), has reproached the Sudanese government for continuing to impede the delivery of humanitarian aid for the Darfur region. Organizations such as the Technisches Hilfswerk and the Malterser Hilfsdienst attempt in vain to transport goods into the region, reports Müller at the end of an African journey in Nairobi. Also, the truce in the west of Sudan was not respected, contrary to statements from Khartoum, she added" (author's translation).

In short, humanitarian emergencies are news for a short period of time. Relatively close contact between aid workers and journalists helps bring them to the attention of newspaper readers in the early stages of a crisis. In long-lasting emergencies, however, news media lose interest. Sudanese state repression of media and aid organizations further contributes to the observed decline of the humanitarian frame in reporting. Unlike the criminal court process, which also drags out over a long time, at least from a journalistic perspective, humanitarian work does not even produce spectacular events along the way such as an indictment against a country's president. Media do report the occasional release of NGO reports, but such releases do not produce the same cascade of articles and editorials that an ICC decision evokes. 
THE JOURNALISTIC FIELD, THE DIPLOMATIC FIELD, AND THE COLORING OF REPORTS

Journalistic citations of the civil war and aggressive-state frames provide initial information about the role of the diplomatic field and about how news media communicate that field's mode of framing the conflict to a broad public. The civil war frame is important for diplomatic activity, even if diplomats expressed little sympathy for the term itself in the context of Darfur. Diplomats whom I interviewed, after all, gave as their primary purpose the settling of armed conflict, and the civil war and aggressive-state frames (which our coding scheme measured) come closest to a broader notion of armed conflict.

Citations of the civil war frame show a particular pattern in at least two ways (see figure 23). First, for most time periods, they are less numerous than crime frame citations but more frequent than humanitarian frame citations. Second, citations of the civil war frame over time contrast remarkably with references to the crime frame. The two frames develop over time in opposite directions: the civil war frame increases when the crime frame declines and vice versa. The graph thus seems to display a conflict between the uses of these contrasting frames, in line with the opposing institutional logics of the criminal justice and diplomatic fields discussed above. Again, while criminal law is interested in stigmatization and exclusion and oriented toward procedure, diplomacy is concerned with including power holders and oriented toward substantive outcomes. When one perspective reigns, it seems to do so at the expense of the other. This tension between the two frames does not explain, however, why the armed conflict theme throughout fares more prominently than the humanitarian emergency trope but less so than the crime frame. What characteristics of the diplomatic field and its relationship with the journalistic field may explain this pattern?

Journalists draw on diplomats as sources of information with some regularity. A German correspondent mentioned "embassy people" as informers; a US journalist referred to "UN people"; an Austrian correspondent reported about her conversations with "diplomats"; three British interviewees spoke, respectively, about sources among "UN and embassy people," especially from the United States and the United Kingdom; "Western diplomats"; and more generally, "diplomats in Khartoum"; a French journalist told me that diplomats in Paris provided information. In short, the majority of journalists I interviewed 
explicitly listed actors from the diplomatic field as important sources of information. This should help explain why diplomatic concerns with Darfur, framed as an armed conflict, and concerns with the establishment of peace appear relatively frequently in journalistic reports.

Yet journalists also frequently cite humanitarian agencies as informers. Why, then, do frames that focus on armed conflict appear more often in media reports than the humanitarian frame does (and why less often than the crime frame)? Part of the answer lies in the nature of diplomacy and its value for media organizations. Much diplomatic work, similar to that of aid agencies, is tedious and drawn-out from a journalistic perspective. Even so, diplomatic proceedings occasionally yield spectacular moments that may not be comparable to an indictment by the ICC, but are newsworthy nevertheless. The openings and the conclusions of peace negotiations are such instances. While not "media events" as Dayan and Katz (I992) describe them for the live broadcasting of history, they are still events, rituals that attract media attention. Subsequent news reporting should reflect with particular clarity the logic and framing of diplomacy. In the case of Darfur, the signing of the Abuja Peace Agreement on May 5, 2006, and the beginning of the Doha peace process in February 2009 are such moments (see figure I7, chapter 6). Both events fall into the time frame of our analysis. A close look at figure 23 reveals potential consequences for the framing of the conflict in media reports. We note that, at the time of the signing in Abuja, the crime frame lost ground against the civil war and aggressive-state frames. How, specifically, was the signing of the Abuja treaty on May 5, 2006, represented in the media?

In Switzerland, the Neue Züricher Zeitung (NZZ) paid close attention to the Abuja peace negotiations in the days before and after the treaty's signing. A May 4 article reported about an extension of the deadline ("Deadline for Darfur Agreement Again Extended" [Frist für Darfur-Abkommen erneut verlängert]). The following day the paper ran the article "Pressure from the USA on Parties in Darfur" (Druck der USA auf die Parteien in Darfur). It told readers that Assistant Secretary of State Robert Zoellick was sent to Abuja to pressure the negotiating parties. The article interpreted this intervention as a reflection of the Bush administration's domestic concerns. The highly mobilized US public perceived that its government's deeds had not lived up to its rhetoric. Finally, on May 6, 2006, the NZZ featured a lengthy article by Kurt Pelda from Nairobi about the signing of the Abuja agreement. Entitled "Convergence among Conflict Parties in Darfur" (Annäherung 
der Konfliktparteien in Darfur), the article detailed the agreement and spelled out reasons for skepticism about its effectiveness. Other Darfurrelated articles in May reported primarily about ongoing efforts to send a UN peacekeeping mission into the region. Additional information on Abuja, specifically about two rebel groups' continuing refusal to sign the agreement, appeared in two brief pieces on June 2.

In France, Le Monde reported on Abuja on May 6, 2006, the day after the signing, but the report focused more on the rebel factions' refusal to support the agreement than on the signing itself. One day later a 253word front-page notice was followed by a lengthy article in which Philippe Bernard offered a more detailed assessment of Abuja. A few more references on the following days culminated in a May 9 editorial entitled "Hope in Darfur" (Espoir au Darfour). The title and text spoke of hope, but hope modulated with substantial cautionary notes. Only on June 3 did Le Monde report about Abuja again, and this time the focus returned to the continuing refusal of two major rebel factions to sign the agreement.

Elsewhere, the Guardian of London also published two informative pieces on Darfur on May 6 and 8, 2006, respectively. These articles were followed, a full week later and again during the second half of May, by reports on the continuing violence and the refusal of two rebel groups to sign. Similarly, the Süddeutsche Zeitung of Munich printed several brief press agency reports released just before and after May 5, 2006 (AP, Reuters, Agence France Presse). The paper supplemented these reports with a portrait of a central diplomatic actor, Salim Ahmed Salim, chief negotiator for the AU in Abuja. This string of articles finally culminated in a May 8 editorial by then-Africa correspondent Arne Perras entitled "A Bit of Peace for Darfur: Treaty between Government and Rebels Provides First Hope for West Sudan" (Ein bischen Frieden für Darfur: Das Abkommen zwischen Regierung und Rebellen gibt erstmals Hoffnung für den Westsudan). A few subsequent Darfurrelated articles, appearing in May, focused on other themes, especially the planned UN deployment of a peacekeeping force.

In short, the culmination of the prolonged diplomatic efforts in Abuja was clearly reflected in news media reporting. At least for the period following the ceremonial signing of the treaty, it used the war and aggressive-state frame at the expense of the crime frame (figure 23). Yet, over the long haul, the effect of diplomatic negotiations was weaker than the resonance of ICC decisions examined above.

Data on the beginning of the Doha peace negotiations confirm this observation. This event too was noted in our sample of newspapers, but 
it did not leave profound traces. Consider the following examples. On February I 8, 2009, almost two weeks after the signing, the Irish Times offered the following Reuters message under "News in Short": "Warring sides in Sudan agree to peace talks. Dubai: Sudan's government and a leading Darfur rebel faction agreed yesterday to meet for peace talks and signed a deal with concessions from both sides. The Qatari mediator urged all other rebels and Chad to come to the table. The agreement included measures to aid and protect refugees in Darfur and a commitment by the two sides to continue negotiations in Doha. Rebel group Justice and Equality Movement also wants a prisoner swap."

In Canada, the Toronto Globe and Mail published a front-page article by Geoffrey York on February 26, 2009, that, while mentioning the Doha negotiations, was entitled "Historic Arrest Warrant for Sudan's Leader Sparks Global Debate" - and indeed, for this paper, the court action obviously overshadowed the diplomatic event. In the United Kingdom, I found no contributions by which the Guardian marked the beginning of the Doha negotiations in February 2009. Yet, on March 2, correspondent Xan Rice reported from Nairobi in a short article on page I8: "Fierce Fighting after Darfur Ceasefire Deal." The failure appeared to be more newsworthy than the beginning of talks. In France, Le Monde printed a brief note ("lettre d'information") on page 6 of its February I3, 2009, edition entitled "Meeting between Khartoum and Rebels in Doha" (Rencentre entre Khartoum et les rebelles à Doha). On the same day, the paper featured a front-page article entitled "The President of Sudan Will be Subject to an Arrest Warrant" (Le president du Soudan va être l'objet d'un mandate d'arrêt). Obviously, new information about an upcoming major ICC decision overshadowed the beginning of peace negotiations. It pushed them onto the back pages.

Diplomatic events are thus noted in the media, but they do not make the same splash as do ICC decisions against high-level actors. Compared to the humanitarian aid field, however, the diplomatic field occupies a stronger position vis-à-vis the media as it does produce newsworthy and highly ritualized events. Its position is further strengthened as routine encounters between journalists and diplomats and newsworthy events are supplemented by repeated interventions by highly visible foreign policy and diplomatic actors. If we pick any month-say, August 2007-and consider any single paper-take Germany's FAZ—we find reports about (or quotes by) the following high-profile diplomatic actors: Peter Schumann, leading the UN delegation to southern Sudan and Ali Karti of the Sudanese Foreign Ministry (8/I/2007); the UNSC 
(8/I); the German minister for development, Heidemarie WieczorekZeul (8/2 and 8/I3); Africa experts from the Christian-Democratic and Green factions of the German Bundestag (8/2); UN secretary-general Ban Ki Moon (8/2, 8/1 8, and 8/29); German foreign minister Walter Steinmeier (8/3); Jan Eliasson, the UN special envoy for Darfur $(8 / 4)$; several German legislators (8/5); AU commission president Alpha Dumar Konaré (8/I4); and in the United States, a White House spokesperson $(8 / 25)$. Clearly, statements by these actors with national and often international visibility stand a good chance of being transmitted to a broad public by the news media.

In short, representations of mass violence produced in the diplomatic field fare prominently in media reporting about Darfur. This diplomatic media presence is partly due to journalists' routine encounters with diplomats as informants, relatively rare but noteworthy events produced in the diplomatic field, and the high public visibility of some actors in this field. The latter two factors appear to secure the diplomatic field's better representation in the news media than is granted the humanitarian field. Yet diplomatic framing still declines over time as compared to citations of the judicial frame. Events produced by the ICC demonstrate a particular ritual power (Durkheim [I9I2] 200I) or legitimacy that is based on their communicative quality (Osiel I997) or on their procedure (Luhmann 2004) and that secures them news value. And such news value, reflective of the market forces to which media are exposed, contributes to explaining the dominant position of the crime frame in reporting about Darfur. Finally, the mirror image of trend lines for the crime frame and those frames that speak to armed conflict, where one increases when the other declines (and vice versa), reflects conflicts between the criminal justice and diplomacy fields and their opposing institutional logics.

\section{PATTERNS IN MEDIA: COUNTRY AND REGIONAL CONTEXT, IDEOLOGY, AND GENDER}

Different newspapers, all relatively close to the autonomous pole of their social field, show some degree of homogeneity, in line with expectations; but it would be wrong to deny the variation within the sample of newspapers under study here. As already observed in this book, there are nationally distinct patterns of reporting, even within our group of relatively comparable Northern countries. Larger differences should be expected for Northern versus African countries. And distinctions at lower levels of analysis are likely to add to differences in cross-national 
and cross-regional comparison. Examples of such differences include the paper's ideological orientation and categories of journalists-for example, men versus women. Here I address patterns that bring variety to journalistic representations of the mass violence in Darfur.

\section{Country Patterns in Representations of Darfur}

Nation-specific patterns of media reporting about Darfur are to be expected given our findings in previous chapters. Chapter 3 addresses the exceptional character of American media reports, with their strong allegiance to a criminalizing frame, and chapter 5 shows the affinity of Irish media with the dominant humanitarian approach of their country. While these cases are outliers, variation in reporting along a number of analytic dimensions can be observed across all countries. Figure 25 offers but one illustration for the use of the crime frame across periods by country. While it may be difficult to decipher and explain each country line (not my intention here), and while all countries similarly respond to specific interventions, it is obvious that they do so at different levels.

In short, while I offer a detailed exploration of media reporting for exceptional cases in previous chapters, analyses of the Darfur media

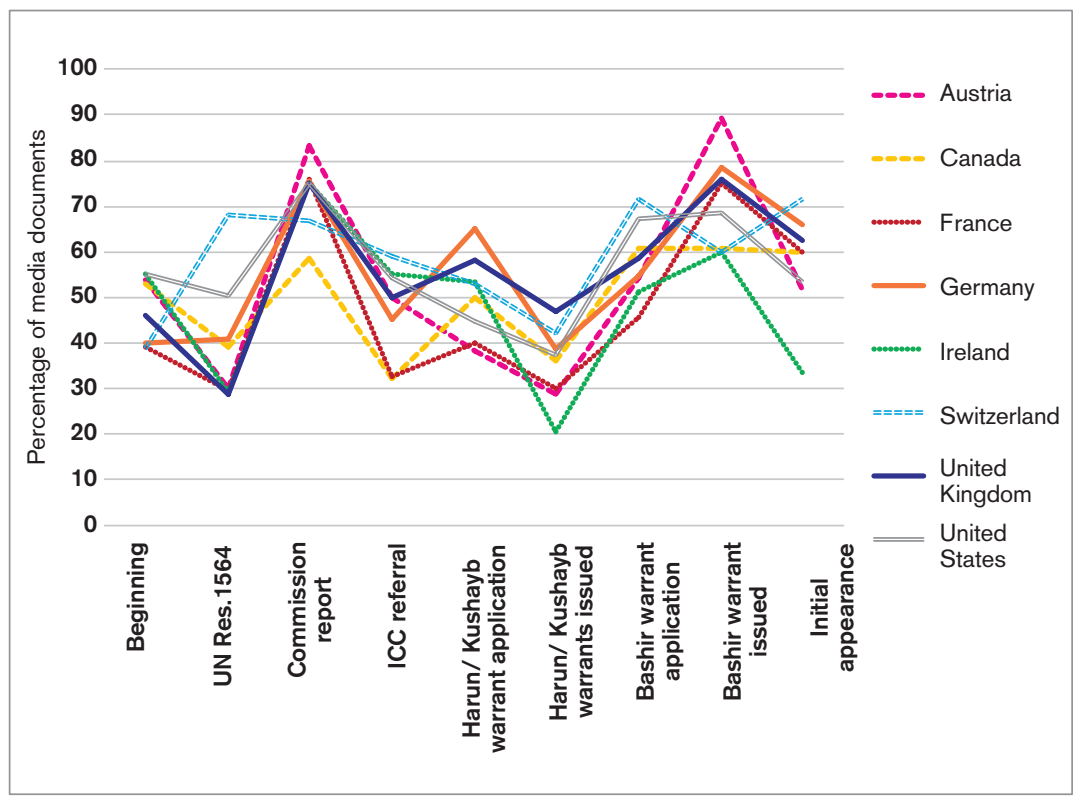

FIGURE 25 . Percentage of newspaper documents citing the crime frame across periods by country. 
data set also reveal country-specific patterns as a general feature of news reporting. I spell out three explanations for such patterns, and I provide illustrative evidence from my interviews with journalists. The first explanation for the fact that reporting varies by country lies in broad structural and cultural differences, even within our group of Northern democracies. The second concerns the specific strength and shape of the fields that supply journalism with information within each country. The third explanation is the varying shape of media fields themselves in cross-country comparison.

First, journalism-even if practiced by expat correspondents in Africa-is imbedded in national contexts. Chapters 3 and 5 show how US and Irish particularities in reporting may be explained by distinct potentials for civil society mobilization and government responsiveness to such mobilization in the United States, and by a humanitarian and development aid focus in Irish foreign policy. Both mobilization and policy foci are themselves driven by carrier groups and national collective memories. Differences were relatively pronounced when the application of interpretative frames and evaluative labels (e.g., genocide) with strong normative implications were at stake, while the reporting of suffering was more homogeneous. Importantly, country-specific differences in reporting indicate an overlap between the journalistic field and cultural and structural features of the national context.

Examples from interviews abound. One Belgian interviewee among the Africa correspondents was greatly inspired by his family's ties with Congo, his homeland's former colony. A journalist with a Sri Lankan family background told me that he is, in light of his family's history, more empathetic with those in the Periphery who express grievances against the Center. A French interviewee spoke about the particular concern of the French state and society with issues of former French colonies, which in the Darfur crisis center on Chad and the risk that the conflict might spill over. ${ }^{\text {is }}$ Clearly, journalists are themselves products of national contexts. Their educational experience and cultural sensitivities differ from country to country, and that likely affects their sympathy with particular topics and frames.

Second, national differences within specialized fields such as humanitarian aid and diplomacy play into media reporting, as these fields provide journalists with information. This chapter has demonstrated how criminal justice, humanitarianism, and diplomacy interpenetrate the journalistic field. And they do so with more or less force depending on the country. Examples from interviews point to the anchoring of humanitarian 
concerns in the churches in Germany; close ties between government aid and humanitarian NGOs in Ireland; and the headquarters of the International Committee of the Red Cross and the particular intensity of diplomatic mediation programs in Switzerland. Given the centrality of these fields as sources of information, journalists are likely to be affected by such particularities of fields in their countries of origin. Indeed, my analysis indicates that media reporting is colored by the particular national features of the fields from which journalists draw information.

Third, the journalistic field itself takes distinct shapes in different countries. ${ }^{16}$ The size of the market differs across countries, and with it the resources available to the media. In addition, publicly subsidized media are stronger in one country (e.g., Germany), while commercial television is more dominant in another (e.g., United States). In addition to structural characteristics of the field, journalistic traditions vary, for example between the "political/literary" press tradition in France and the "objective/informational" model in the United States (Benson 2006:I97-I98; 2013). Also my interviews spoke to national particularities in the journalistic field. Respondents reported, for example, the reluctance of a major French paper to have journalists on the ground in Africa; the incomparably large market of a paper such as the NYT, which provides it with vast resources and many more journalists in Africa than any other paper could afford; and, at the other end of the spectrum, the small size of media markets in countries with less than 5 percent of the US population. Such media depend especially on press releases in reporting about Africa. Their content is consequently less detailed, and some nuances will not be provided. In addition, competitive pressure varies by country and with it the contest for market share. Providing what audiences perceive as sensational and, in reporting about conflicts, offering starker depictions of opposing groups tend to be comparatively more attractive in more competitive national media fields. The Darfur media data set suggests that differences caused by national particularities of the journalistic field are not limited to style, but extend to topical foci and framing as well.

In short, three types of national forces result in nation-specific patterns of reporting: broad structural and cultural distinctions between countries; country-specific shapes of fields that supply media with information; and finally different shapes that media fields themselves take in each country. Topical choices, framing, and styles of reporting are affected, as a comparative analysis of the uses of the term genocide and of analogical bridging to the Holocaust illustrates. 
Using "Genocide" and Holocaust Bridges in International Comparison

The varying use of the term genocide across countries illustrates how the three nation-specific forces outlined above affect country patterns of reporting. As noted earlier, the genocide label and bridging to the Holocaust are especially prominent features of reporting about Darfur in US media. This pattern corresponds closely not only with the centrality of the genocide theme in American civil society and its massive Save Darfur campaign, but also with the use of the term genocide by highranking government actors. A French journalist stationed in the United States spoke to this difference: "In the US you had Colin Powell, who said that [word genocide]. If you have an official using that term, then the media will pretty much follow it. . . But then, in France nobody did that. And the media then started to wonder about it. So the UN is the umpire of this, arbiter of this. So the UN didn't do it. . . . And then I remember Doctors Without Borders not using it."

Figure 26 shows that this journalist's assessment is reflected in the statistics of my news media analysis. Indeed, we find the United States and France to be the outliers at both ends of the distribution. The figure also again confirms the reluctance of media in Ireland and Germany to use the genocide label. ${ }^{17}$

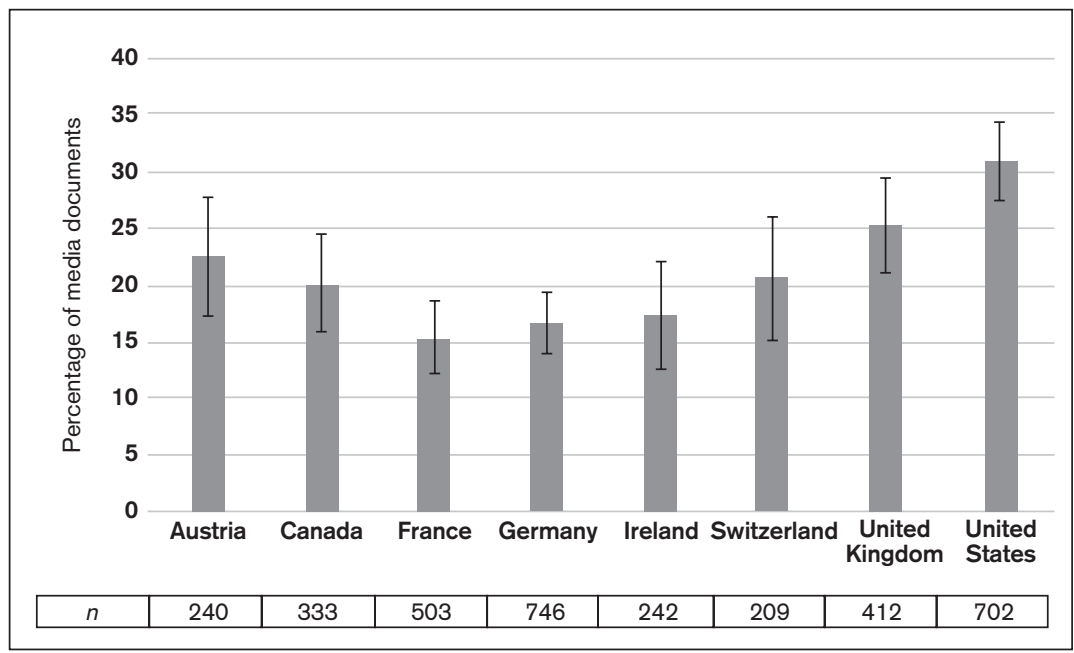

FIGURE 26. Percentage of newspaper documents using the term genocide for Darfur, by country. 
While it is likely that social movements, leading politicians, and news media reinforced each other's preferred terminology, the causal arrow from civil society to the media in the United States is likely to have been strengthened by the competitiveness of the American media market. Here the third condition of nation-specific media reporting identified above is at work: the particularity of the national media field. But broader cultural sensitivities matter also. In Germany a journalist talked about his reluctance to subsume Darfur under the same category (genocide) under which the Holocaust is categorized. In addition to this cognitive impediment, we also encountered normative constraints among German respondents, indicating the standing of the Shoah as a "sacred evil" especially in that country (Alexander 2004a). Consider also Ireland, where a humanitarian complex is firmly established, associated with the country's foreign policy and collective memory, thus contributing to a general hesitance to use strong vocabularies vis-à-vis the Sudanese state. Consequently, the term genocide is used cautiously here too. Irish media reporting shows an elective affinity with the national particularity of the humanitarian field, even if we cannot make out the precise causal path. The first factor identified above, general national cultural characteristics, is here at work. In Ireland it is supported by the strength of the humanitarian field as a source of information-the second force working toward national particularities identified above.

In short, country-specific uses of genocide-as well as metaphorical bridging to the Holocaust-confirm what an examination of Darfur reporting in news media shows more generally: that the journalistic field overlaps with national conditions pertaining to a country's larger structural and cultural characteristics, nation-specific strengths of fields that supply media with information, and particularities of national media fields themselves (see also Benson 2013).

\section{Northern versus African Countries and Group Identification}

Patterns of national distinction in news reporting identified across Northern countries suggest that comparisons between Northern and African news media should be especially pronounced. After all, cultural and structural differences between both regions, differences in the role of specialized fields, and particularities of the media field itself are substantial. A brief examination for one issue must suffice here: the categorization of perpetrators and victims of human rights violations in the conflict. Some media scholars are highly critical of the use of 
ethnic categories in Northern press representations of African conflicts. They charge that Western journalists "swallowed the ethnic interpretation of conflict promoted by interested parties locally" (e.g., McNulty I999:283). Also Wall (2007) observes a tendency in Western media to attribute African violence to tribalism. She argues that reference to long-standing ethnic or tribal affiliations allows Western media to avoid references to the contributions of colonial powers in planting the seeds of conflict. Interviews that Wahutu Siguru, a doctoral student at the University of Minnesota, conducted with African journalists from Kenya and South Africa show that they expressed similar critical sentiments regarding the ethnicization of conflicts in Africa by their Northern colleagues (Siguru and Savelsberg 2013; see also Mamdani 2009b).

Yet one of the most scathing critiques of simplified uses of ethnic categories in debates about Darfur was written by Rob Crilly (2010), a British journalist. Also, many of my interviews with Africa correspondents from the Global North reveal considerable sensitivity toward oversimplified depictions of conflicting parties along ethnic lines. Further, systematic analyses of African media reporting disclose astonishingly small differences in the use of vocabulary. One of the few content analyses of African newspapers and their reporting about Darfur in fact finds astounding similarities with Northern media reports: "a tendency to report on the violence in an oversimplified racialized way" whereby "fault lines in this conflict are often the same as those used by western media" (Ray 2009:I72, I76).

We are thus confronted by a double paradox: that Northern journalists speak critically of ethnicized or racialized descriptions of African conflicts—exactly the practice for which they are reproached—and that African media do not seem to differ fundamentally from their European and North American counterparts-despite the disdain with which their journalists speak about Northern media. Part of the explanation lies in the nature of journalistic genres. Space constraints lead to simplified narratives that do not live up to the differentiations and elaboration of insights into the historical construction of group identities that we might encounter in interviews with journalists. But further, if major Northern newspapers-leaders in the world of journalism in countries such as the United Kingdom, France, Germany, and Canada-suffer from a shortage of resources and resulting constraints in innerAfrican travel, African journalists suffer these limitations even more. This shortage of resources results in restrictions on investigative journalism and creates, instead, dependency on news agencies or reports 


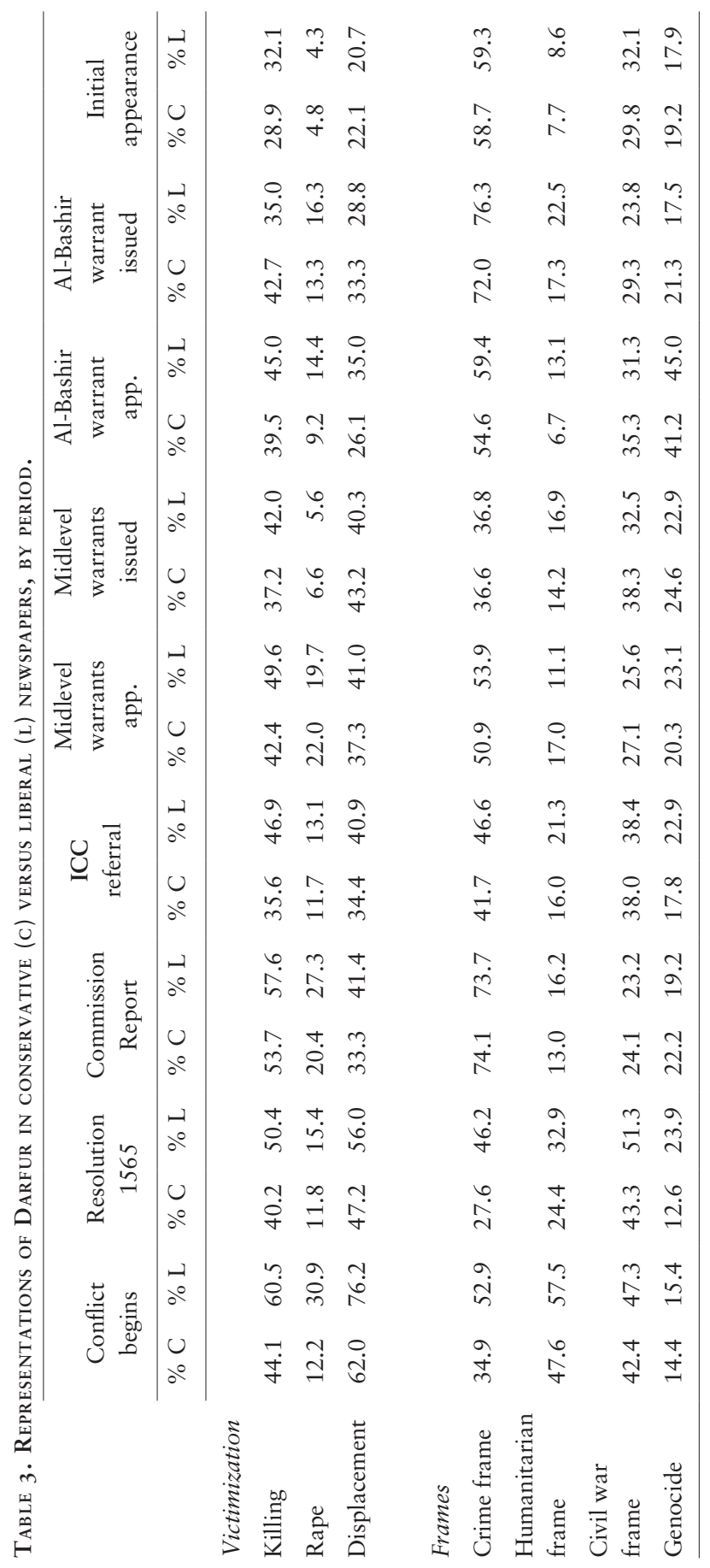


issued by international organizations or INGOs. The dependency of African journalists, in particular, on such sources must be considered at least one explanation for the relatively small difference in patterns of media reporting between Global North and African papers. A thorough comparative investigation of African and Northern journalistic work on mass violence in African countries goes beyond this book's purposes, but a first promising effort is under way (Siguru, in progress).

\section{Below the Level of Nation-States: Media Ideological Orientation}

This book has paid little attention to patterns below the level of the nation-state, as such an effort would distract from its central arguments. Yet here I briefly highlight two such forces, and I recommend them for future investigation. My choice of a liberal and a conservative paper in each country lends itself to a comparison along ideological lines. Table 3 depicts differences across a number of central dimensions used to describe the violence in Darfur. Interesting patterns emerge, patterns that also speak to the cultural strength of the institutional interventions I am concerned with here.

The data in table 3 reveal that a substantially greater percentage of articles on Darfur appearing in liberal-leaning newspapers were inclined to report the victimization of Darfur in the first period of the conflict. At that stage they were also much more likely to use the crime and the humanitarian frame than they were the civil war frame or the genocide label. Yet, interestingly, differences between conservative and liberal papers diminished as international organizations and eventually the ICC intervened. Both the reporting of victimization and the framing of the conflict became more similar across the ideological spectrum.

Why the initial overrepresentation of the recognition of suffering and use of crime labels in articles about Darfur in liberal-leaning media, an overrepresentation that multivariate analyses prove to be significant for the entire reporting period (Savelsberg and Nyseth Brehm 2015)? A necessarily speculative answer points to the left-liberal tendency to speak on behalf of weaker members of society, those suffering from oppression. But why the growing similarity in reporting after the judicial interventions? Again, I can only speculate at this point, but it appears as though such assimilation across ideological lines may result from the ritual power or procedural legitimacy, or both, that media, including and possibly especially conservative media, attribute to formal 
institutions of law. Remember that previous literature on the legal processing of Auschwitz at the Frankfurt trial detected an affinity between judicial and journalistic narratives, identifying a close correspondence between judicial depictions of mass atrocities and journalistic accounts (Pendas 2006). Above I also cite work that finds a closer resemblance of media and textbook narratives of the My Lai massacre to the judicial account than to the accounts of the Peers Commission and Seymour Hersh's Pulitzer Prize-winning book (Savelsberg and King 20II).

In short, a brief comparative analysis of conservative and liberal news media across intervention periods suggests that ideological orientation matters, but that its weight diminishes over time. Again, judicial interventions do not just contribute to the intensity of reporting but also shape the quality of journalistic narratives. Importantly, they at least partially neutralize the ideological orientation of media organizations.

\section{Below the Level of News Media: Journalist Gender}

Much feminist literature has documented that even in scholarly work the observer's standpoint colors his or her depiction of social reality (e.g., Harding I996; D. Smith I992). What applies in academia likely also holds true in the world of journalism. I thus expect gender to matter in media reporting about Darfur, especially in light of the gendered nature of mass violence and genocide (Burkhardt 2005; Hagan 2003; Kaiser and Hagan 2015). What gender-specific patterns might be hidden in the Darfur media data set? Patterns should be most pronounced in reporting about rape, which I examine here.

Comparing the reporting of rape in articles written by male and female journalists across our time periods indicates that females were more likely to speak to the issue of rape than males in their reports about Darfur, at least in the majority of periods (see figure 27). Multivariate analyses show that this difference holds up when we consider the entire time period and when we control for other variables (Savelsberg and Nyseth Brehm 2015). This pattern may reflect female reporters' greater empathy with female victims. Note, though, that the overrepresentation of rape reporting by female journalists applies especially in the first period, when most media accounts were still based on INGO and IO reports, and in the periods around the ICC decisions concerning President al-Bashir, when much reporting came from The Hague. This may indicate the prevalence of female reporters writing about Darfur 


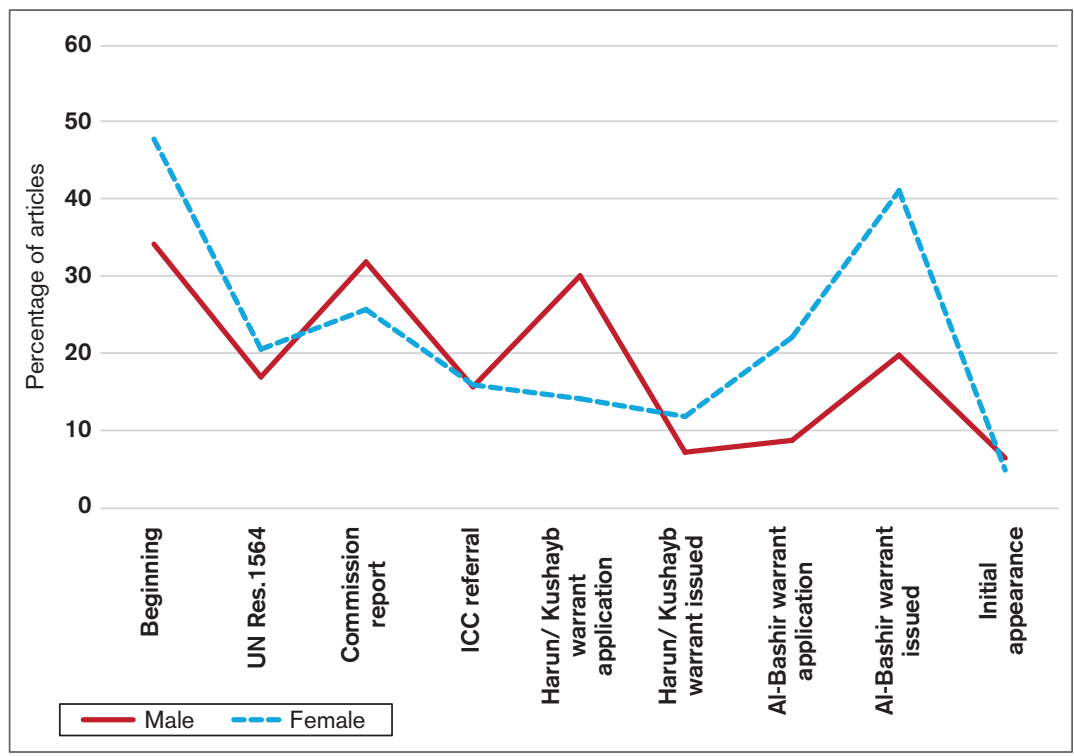

FIGURE 27. Percentage of newspaper documents referencing rape, by period and gender of journalist.

from Europe or North America. In addition, however, female correspondents who do report out of Darfur may have easier access to information about rapes. Male journalists certainly face greater challenges in interviewing female rape victims, a challenge noted in more than one of the interviews I conducted.

Additional analyses, not shown here, indicate for the macro level that media from countries with a larger percentage of females among their correspondents were substantially more likely to include issues of rape in their reports about Darfur.

In short, the gender of journalists mattered in reporting about Darfur, at least with regard to the issue of rape. More generally, patterns below the level of the nation-state, such as the newspaper's ideological leaning and the gender of its journalists, merit future investigation.

\section{CONCLUSIONS: JOURNALISTIC REPRESENTATIONS AND WHY THEY MATTER}

Analysis of the Darfur media data set shows that the first wave of mass violence in Darfur in 2003 was almost completely neglected by news media. Massive suffering is not a sufficient condition for media to report 
an event. During the second stage, immediately following the second wave of the violence, however, reporting experienced the first of two major peaks. During this period UN secretary-general Kofi Annan addressed the violence in his speech before the General Assembly on the tenth anniversary of the Rwandan genocide. The high visibility of his statements, and the weight added by his analogical bridging to the horrific and, by 2004, widely recognized Rwandan genocide, was a major contributor to this first outburst of reporting. Also, in national contexts, interventions by politicians of high standing who were engaged with the Sudan conflict and human rights issues contributed to this first peak. The German story of former justice minister Gerhart Baum and his interaction with one of the newspapers under analysis provided an example. Political initiatives were accompanied, and partly preceded, by initiatives from civil society groups, including the USHMM and evangelical Christian groups in the United States. While the intensity of reporting declined somewhat during the subsequent two years, it still remained at a relatively high level. These years were filled with UN and ICC interventions, including the ICID report, the UNSC's referral of the Darfur case to the ICC, intense campaigns by human rights INGOs, and substantial engagement by humanitarian aid organizations.

The second peak of reporting occurred after the ICC issued the first indictments, without which it certainly could not be explained. Yet it was followed in subsequent years by a dramatic decline in the intensity of reporting about Darfur, despite the continuing deprivation of the population in refugee and IDP camps, as well as continued killings, rapes, and displacements, albeit at a reduced level. After this point, Bourdieu's observation proves true: media tend to raise one episode of mass violence, only to drop it when its newsworthiness declines. They moved on from Darfur to South Sudan and then to the Central African Republic, soon dropping those cases to turn to northern Nigeria, Syria, Ukraine, and elsewhere, and so the journey of migrating attention continued. Such processes reflect the declining market value of prolonged suffering in the media field, a factor strengthened by growing restrictions on journalistic work imposed by the government of Sudan. But we also saw that judicial interventions delayed this decline in the case of Darfur and continued to affect the framing of news reports in later stages, albeit at a lower incidence of reporting. Bourdieu's thesis is thus partly confirmed, but it warrants modification: interventions by civil society, states, and the judicial field have the capacity to delay the drop-off 
in coverage, keeping journalistic attention alive over several years and coloring interpretations of mass violence.

My analysis shows in fact that interventions by the judicial field, specifically the ICC, colored reporting about Darfur. Several intervention points were followed by substantial increases in citations of the crime frame as a lens through which journalistic sources of information interpreted the violence. Advanced statistical analyses presented elsewhere confirm these patterns (Savelsberg and Nyseth Brehm 2015). Judicial interventions are also followed by increases in reporting about some forms of violence such as killings and rapes, albeit much less about displacements and the destruction of livelihood. These judicial intervention effects might be surprising, given the major obstacles Africa correspondents experience in terms of geographic distance from the court, the distinctiveness of legal language, and the mismatch between the time horizon of legal proceedings and the fast pace of journalistic work. But these impediments, it seems, are partially overcome by the particular ritual force of judicial interventions and the legitimacy that court proceedings enjoy, as previous studies on the journalistic processing of mass violence have suggested (Pendas 2006, Savelsberg and King 20II). Impediments are further overcome as most news media send specialists for judicial affairs and international institutions to The Hague to cover dramatic legal pronouncements. Indictments of a minister and certainly of a head of state such as Omar al-Bashir are among these events.

A word of caution is warranted, though, for judicial interventions did not succeed in the long run in keeping the case of Darfur on the radar of public and media attention. They did, however, lead to new peaks in the number of narratives that applied the crime frame to the mass violence in Darfur, even in the late stages of the period under study.

Proponents of a humanitarian emergency frame find less comfort in the information from the Darfur media data set. It is true that Africa correspondents highlighted the importance of the humanitarian aid field in informing journalistic work. Accordingly, the humanitarian emergency frame manifested most prominently in the initial phases of reporting. Yet it declined quickly and dramatically. This decline, it seems, resulted from several forces. First, continued suffering soon stops being news. Notions of newsworthiness and market forces trump victims' need to get the story of suffering before the public. Second, the government of Sudan barred many humanitarian aid organizations from Darfur, 
especially after it began suspecting them of being sources of information on which charges against Sudanese state actors were based. The third factor is self-censorship of the remaining aid organizations, whose representatives feared that they too would be forced to leave the country for speaking out about the violence. Fourth and finally, humanitarian aid delivery is continuous. It does not produce dramatic moments. Here it differs from both the judicial and the diplomatic field.

Indeed, citations of the civil war frame appeared more prominently (and declined less rapidly) than references to the humanitarian emergency frame. Remember that ending the fighting usually dominates the diplomatic agenda. Diplomatic activities should thus correspond to war frames. But why should they affect media reporting? On the one hand, diplomacy, just like humanitarian aid, proceeds continuously and hidden from public view. On the other hand, diplomatic work differs from aid delivery in its display of performative, often dramatic moments. Examples are the beginnings and conclusions of peace negotiations, often opened or sealed by prominent actors from the world of politics and diplomacy who carry more newsworthiness than doctors, nurses, logistics experts, or truck drivers who deliver food or medicine to devastated areas (see figure $\mathrm{I} 7$, chapter 6).

In short, all three fields examined in this book, judicial (especially), humanitarian (initially), and diplomatic (intermittently) leave their traces in journalistic reporting. And so do the political field and media markets. While the types of media analyzed here, and the journalists who serve as Africa correspondents, enjoy a relatively high degree of autonomy compared to other news outlets, the intensity and interpretive implications of reporting cannot be understood without reference to such forces. Suffering and its causation alone certainly are insufficient conditions for journalistic attention or choices of interpretive frames.

While this chapter focuses on patterns of reporting over time and along intervention points, it also examines the global versus national controversy and confirms many previous observations in this book. In line with globalization arguments (e.g., Boyle 2002; Boyle and Meyer I998; Frank, Hironaka, and Schofer 2000; Meyer, Ramirez, and Soysal I992), patterns of reporting, its intensity, the acknowledgment of diverse forms of suffering, and the uses of various frames across periods follow similar paths in all countries. Yet they do so at different levels. The likelihood of reporting about Darfur, of speaking about the killings, and of using the crime frame or the genocide label is more 
pronounced in some countries than in others. As analyzed throughout this book, the country-specific mobilization of civil society; the relative weight of different fields in a country; cultural sensitivities and policy practices, often rooted in the type and intensity of national memories; and the nature of the media field—all are decisive forces. Thus, for example, the frequency of reporting is especially high in the United States and Germany and-if controlled for the smaller number of papers-in Ireland, compared to the other five countries; the use of the crime frame is pronounced in the United States and Germany; and the humanitarian frame is privileged in Ireland.

Below the level of the nation-state, the ideological orientation of newspapers matters, with left-liberal papers having been more likely to address the Darfur issue in the early stages of the mass violence-a difference that became neutralized with the onset of formal interventions. Finally, individual-level variables also affect reporting. Female journalists are more likely, for example, to address issues of rape. Again, both ideology and gender effects are confirmed in multivariate analyses (Savelsberg and Nyseth Brehm 2015). In addition, gender effects translate to the macro level as media in some countries made more use of female journalists in reporting about Darfur than their counterparts in others.

What do these patterns mean for a sociology of the journalism field? Journalism's relationship to other fields is obviously crucial to understanding patterns of reporting on mass violence. This finding is in line with efforts by Pierre Bourdieu (1998) and his followers (Benson I998, 2006) to develop a sophisticated model of journalism vis-à-vis other fields. Remember, Bourdieu depicts the world of fields in a spatial model, defined by a vertical axis representing increasing volumes of diverse forms of capital, and by a horizontal axis depicting the proportion of cultural-to-economic capital owned by specific actors (with cultural capital concentrated at the left and economic capital at the right end of this continuum). Bourdieu places media in the upper half of that space, as a dominating force. On the horizontal axis he locates media on the left side of the spectrum, as cultural producers, dominated in this respect. But Bourdieu also differentiates between types of media. Represented on the far left of the horizontal axis, where cultural capital reigns, are highly autonomous media with little or no economic prowess (e.g., small literary journals). The center and, even more, the right side of the horizontal dimension are inhabited by institutions in which concern with economic capital trumps engagement with cultural capital (e.g., commercial TV networks). Prestigious newspapers analyzed in 
this book would be found toward the left side of the horizontal axis; my interview data provide insights into the relative autonomy that Africa correspondents experienced when reporting about mass violence in an African context.

Future work should examine media in other places on the horizontal axis, media with stronger emphases on either cultural or economic capital than applies to the newspapers under examination here. I suggest, though, that the present papers' simultaneous attention to cultural and economic forces secures them prestige as well as access to policy makers and to those societal groups that pay special attention to foreign and international events. In this realm they exercise a force Bourdieu (I998:46) attributes to actors in the journalistic field generally: as "controllers of means of public expression" who "sanctify" events. Indeed, past research has shown that newspapers can directly influence public opinion, especially on foreign and international issues far removed from citizens' lifeworlds (McCombs and Shaw 1976; Wanta and Hu I993). Partly mediated through public opinion, they also appear to affect foreign policy (Walgrave, Soroka, and Nuytemans 2008), the allocation of foreign aid (Rioux and Van Belle 2005), and presidential actions (Wood and Peake I998).

The above analysis warrants a word of caution against exaggerated theses regarding the mediatization of politics (Strömbeck and Esser 20I4). Journalism itself may depend on the sanctification of events by political actors, as it did in the case of Darfur. Further, this chapter shows that it is not sufficient to locate the journalistic field vis-à-vis economic forces. In this the chapter supports recent comparative work on media fields by Rodney Benson (2013). Adding to Benson's insights, I argue that journalism also depends on informational and interpretive input from the fields of diplomacy and humanitarian aid and —of particular weight according to the data analyzed in this chapter-the judicial field. Finally, no matter the causal direction between the journalistic field and the fields of politics, humanitarianism, diplomacy, and law, only through media reporting do national civil societies and a global public become "spectators" of suffering in distant lands (Boltanski I999). And spectators they have to be before they can mobilize to demand or contribute to aid, peacemaking, and justice. 